\title{
Memória coletiva e construção de identidade linguística nas narrativas de Alfredo Troni e Uanhenga Xitu
}

\author{
Manuel da Silva Domingos \\ Nsimba José \\ Faculdade de Letras da Universidade Agostinho Neto (Angola)
}

Se a metrópole imperial tende a ver a si mesma como determinando a periferia (seja, por exemplo, no brilho luminoso da missão civilizatória ou na fonte de recursos para o desenvolvimento económico), ela é habitualmente cega para as formas como a periferia determina a metrópole (Pratt, 1999, p. 31).

\section{Introdução}

O presente estudo, que toma por base as formulações teóricas alicerçadas nos domínios dos estudos da memória coletiva e discurso, procura, de forma sucinta, demonstrar a maneira como os aspectos socio-históricos, culturais e discursivos se articulam e se materializam linguisticamente nas narrativas de Alfredo Troni e Uanhenga Xitu. Alfredo Troni, jornalista e escritor, nasceu em 1845, em Coimbra, Portugal. De formação ideológica republicana e socialista, participou em iniciativas políticas e esteve ligado ao movimento estudantil, o que lhe condenou ao desterro em Angola, em 1873, onde viveu cerca de 30 anos. A sua obra 'Nga Mutúri' foi publicada pela primeira vez em folhetins em 1882. A edição à nossa disposição é uma reedição de 2014, sob chancela da União dos Escritores Angolanos.

Já Uanhenga Xitu, nome Kimbundu de Agostinho André Mendes de Carvalho, nasceu a 29 de Agosto de 1924, no município do Icolo e Bengo, província do Bengo, Angola, e faleceu em Luanda no dia 13 de Fevereiro de 2014. Dentre várias outras obras literárias, publicou 'Mestre Tamoda Tamoda' (1974), 'Mestre Tamoda e Outros Contos' (1977), 'Manana' (1974), 'Maka na Sanzala' (1979) e 'Vozes na Sanzala (Kahitu)'. Esta última obra, conjuntamente com a de Alfredo Troni, será analisada no nosso estudo, conforme ilustra o título do trabalho. $\mathrm{O}$ capítulo é subdivido em duas partes, sendo que a primeira aborda questões sobre a memória coletiva e a segunda, aspectos que evidenciam a materialidade linguística dessa memória e, consequentemente, o estilo e a variação linguística que as narrativas em estudo espelham. 


\section{Texto, o lugar de experiências humanas}

'Vozes na Sanzala (Kahitu)' e 'Nga Mutúri', como quaisquer outros textos, não são universos fechados, ou seja, configuram-se como tecidos, espaços permeáveis onde é notável a interseção de vários saberes que revelam toda uma experiência sensível relativa aos aspectos de ordem material e imaterial (José, 2016).

Essa visão dialoga com a de autores como Bakhtin (1981) para quem a polifonia representa consciências (vozes). Estas estão contidas dentro de uma obra literária e são plenivalentes, dito em outros termos, são plenas de valor e mantêm com as outras consciências do discurso uma relação de absoluta igualdade, como integrantes do grande diálogo. Koch e Oesterreicher (apud Longhin, 2014) também pertencem a mesma linha argumentativa. Visando distinguir as duas grandezas históricas, língua e texto, reavaliam-se os níveis de atividade linguística que fundamentam o pensamento de Eugene Coseriu - o universal, o histórico e o individual, respectivamente.

Assim sendo, o nível universal diz respeito à capacidade humana, biológica de falar uma língua; o nível histórico refere-se às línguas enquanto produto histórico das sociedades; e o nível individual diz respeito à maneira particular como cada ser humana fala uma língua. Particularmente, dentro do nível histórico, de onde emerge o conceito de Tradições Discursivas, os dois autores distinguem o domínio da língua histórica particular e o domínio da tradição dos textos. No âmbito das línguas históricas, existem as técnicas do sistema e da norma. Ao contrário do sistema que abrange as possibilidades léxico-gramaticais de uma língua, a norma abarca as possibilidades do sistema que são efetivamente usadas.

No domínio dos textos, questão central do presente estudo, a historicidade tem a ver com o acervo de textos já ditos ou escritos, armazenados na memória da comunidade. Aqui, pode-se considerar as Tradições Discursivas, que têm entre outros teóricos Kabatek (2005), para quem elas são a repetição de um texto ou de uma forma textual ou de uma maneira particular de escrever ou falar que adquire valor de signo próprio (portanto é significável). Em conformidade com o autor, essa tradição pode-se formar em relação a qualquer finalidade de expressão ou qualquer elemento de conteúdo, cuja repetição estabelece uma relação de união entre atualização e tradição, ou seja, "qualquer relação que se pode estabelecer semioticamente entre dois elementos de tradição (atos de enunciação ou elementos referenciais) que evocam uma determinada forma textual ou determinados elementos lingüísticos empregados" (Kabatek, 2005, p. 159).

A visão do autor acima referenciado converge com a de Sanderléia Roberta Longhin que entende que as Tradições Discursivas têm um viés fortemente textual e pragmático 
consistem em modelos textuais, social e historicamente convencionalizados, que integram a memória cultural de uma comunidade, sendo mobilizados na construção e na recepção do sentido. Considerando que tudo que é dito ou escrito se realiza por meio de textos, estão em jogo uma intenção de dizer, o acervo lexical e gramatical da língua, os esquemas textuais normativos, as convenções sociais e históricas (Longhin, 2014, p.9).

Equivale a dizer que todo enunciado não deixa de ser sintomático de valores historicamente consagrados na memória coletiva de um povo. Daí a razão de termos aludido anteriormente, em outros termos, que o texto, não importa qual seja a sua natureza e/ou finalidade comunicativa, acaba por ser o lugar onde ressoam várias vozes, sendo que algumas delas evidenciam saberes compartilhados relativos às comunidades a que pertecem ou não. Assim, é natural que num texto estejam evidenciados elementos de diversas origens e naturezas, cruzando-se para participar do sentido do que é, por exemplo, dito ou escrito, considerando, dentre outros aspectos, os mecanismos de construção textual, como são os casos da coesão e da coerência. Portanto, considerando o acima exposto, torna-se imprescindível debruçar-se sobre aquilo que se convencionou designar por memória coletiva, elemento muito patente nas obras selecionadas para o presente estudo.

\subsection{A questão da memória coletiva}

Não são poucos, no domínio das ciências humanas e sociais, os estudos sobre memória, noção discutida paralelamente com a da identidade ${ }^{1}$. Na verdade, os graus de desenvolvimento desta temática variam de autor para autor, cabendo a quem realiza uma pesquisa dessa natureza definir uma perspectiva que converge com os seus objetivos. Deste modo, em conformidade com os propósitos do nosso trabalho, privilegiamos as premissas teóricas de autores como Maurice Halbwachs e Joël Candau. Para este último autor, considerando que identidade, memória e

1. Tal como vimos acima, a expressão identidade, há muito que é abordada por pesquisadores, dividindo-os, muitas vezes. Jean-Pierre Warnier (2000), na sua obra A mundialização da cultura define identidade como um conjunto de repertórios de ação, de língua e de cultura que permitem a um indivíduo reconhecer a sua dependência de certo grupo social e de se identificar com ele. Apesar disso, esta categoria não depende somente do nascimento ou das escolhas dos sujeitos, na medida em que, em vários planos, como político e nas relações de poder, os grupos podem determinar identidade a membros de uma sociedade. Há um relato de Jean-Pierre Warnier de que nos servimos de exemplo para contextualizarmos o assunto em causa. Os franceses têm tendência para amalgamar os imigrantes da África Ocidental numa única identidade africana, mesmo que, entre eles, nunca se reconheçam. Repare-se que alguns falam línguas diferentes. Alguns são cristãos, outros muçulmanos. Para o mesmo autor, estas observações permitem perceber que é, sem dúvida, mais pertinente falar-se de identificação do que de identidade, e que a identificação é contextual e flutuante. É por isso que assinala que no quadro da mundialização da cultura uma mesma pessoa pode assumir múltiplas identificações. Estas podem entrecruzar diferentes elementos de língua, de cultura, de crenças em função de contextos, levando a que se questione, dentre outros aspectos, o que se legitimou chamar por identidade nacional. 
patrimônio são palavras-chave na consciência contemporânea, pode-se reduzir a duas se se admitir que o patrimônio é uma dimensão da memória.

Ao contrário da identidade que se refere a um estado, a memória é uma 'faculdade'. Ambos os termos são indissociáveis, ou seja, entrecruzam-se, reforçam-se mutuamente. Por isso diz-se que a memória fortalece a identidade, quer individualmente, quer coletivamente, ou ainda "não há busca identitária sem memória e, inversamente, busca memorial é sempre acompanhada de um sentimento de identidade, pelo menos individualmente" (Candau, 2012, p.19).

Este pensamento põe em causa o argumento do sociólogo francês Halbwachs sobre o que ele denomina «memória colectiva», processo social de reconstrução do passado vivido e experimentado por um determinado grupo, comunidade ou sociedade. Este passado vivido, segundo ele, é distinto da história, a qual se refere mais a fatos e eventos registrados, como dados e feitos, independentemente destes terem sido sentidos e experimentados por alguém. Embora reconheça que a memória seja uma faculdade inerente a um indivíduo, admite que as lembranças podem organizar-se de duas maneiras distintas, tanto agrupando-se em torno de uma pessoa, que as vê a sua maneira, como distribuindo-se dentro de uma sociedade, da qual são imagens parciais. Assim, existiriam memórias individuais e memórias coletivas. Não obstante, conforme o indivíduo participa de uma ou de outra, o mesmo adotaria duas atitudes muito diferentes e até opostas:

Por um lado, suas lembranças teriam lugar no contexto de sua personalidade ou de sua vida pessoal as mesmas que lhes são comuns com outras só seriam vistas por ele apenas no aspecto que o interessa enquanto se distingue dos outros. Por outro lado, em certos momentos, ele seria capaz de se comportar simplesmente como membro de um grupo que contribui para evocar e manter lembranças impessoais, na medida em que estas interessam ao grupo (Halbwachs, 2012, p.71).

As lembranças, quer individuais quer grupais, podem ser reforçadas pelos lugares de memória, na acepção de Nora (1981). Estes podem ser: lugares materiais, onde a memória social se ancora e pode ser apreendida pelos sentidos; lugares funcionais porque têm a função de alicerçar memórias coletivas; e lugares simbólicos onde essa memória coletiva se expressa e se revela. Quanto à tipificação da memória, Candau propõe, numa perspectiva antropológica, uma taxonomia das diferentes maneiras como ela se manifesta.

Segundo Nora (1981), há três tipos de memórias: a protomemória (memória de baixo nível), que diz respeito à memória social incorporada, tal como se expressa, por exemplo, nos gestos, nas práticas e na linguagem, cujo exercício é realizado quase automaticamente, ocorrendo quase sem tomada de consciência; a memória propriamente dita, que é, por assim dizer, uma memória de recordação 
voluntária. Feita igualmente de esquecimento, esta memória possui extensões, como os saberes enciclopédicos, as crenças, as sensações e os sentimentos, que podem beneficiar-se de extensões artificias que derivam do fenômeno geral da expansão da memória; e metamemória, que é, por um lado, a representação que cada um de nós faz da sua própria memória, o conhecimento que temos dela e, por outro, a construção explícita da identidade.

Em conformidade com o mesmo autor, quando se passa para o nível de grupos, o estatuto da sua classisicação muda ou fica invalidada, na medida em que, por exemplo, a noção de protomemória se torna insignificante porque nenhum grupo humano pode ter uma memória procedual ainda que ela possa ser comum e compartilhada pelo mesmo grupo. Significa que mesmo ao nível de grupos, apenas a eventual posse de uma memória evocativa ou da metamemória pode ser pretendida. É essa eventualidade que aparece subjacente na expressão 'memória colectiva'. Porém, sabe-se que é impossível admitir-se que esta noção seja uma faculdade porque a única atestada, por assim dizer, é a memória individual. "De fato, em sua acepção corrente, expressão «memória colectiva» é uma representação, uma forma de metamemória, quer dizer, um enunciado que membros de um grupo vão produzir a respeito de uma memória supostamente comum a todos os membros desse grupo" (Candau, 2012, p. 24).

Esse argumento prova que, não havendo uma modalidade culturalmente determinada e socialmente organizada, uma parte do grupo é capaz de se recordar de algum assunto de carácter socio-histórico, político, econômico, espiritual ou outro. Portanto, 'Vozes na Sanzala (Kahitu)' e 'Nga Mutúri' evidenciam estes e outros aspectos que explicaremos em seguida.

\subsection{A memória em Vozes na Sanzala (Kahitu) e Nga Mutúri}

Começaremos por analisar a narrativa de Alfredo Troni. Ela retrata a vida de uma mulher, em dois principais momentos. No primeiro, ela, Nga Ndreza (senhora Andreza), que vivia numa aldeia, é levada à cidade, pelo seu tio. Pelas conversas que ouve pelo caminho, dá conta de que o seu tio tinha sido condenado num juramento e para pagar o crime fora buscá-la porque, segundo os costumes da terra, se o tio não tem com que pagar, tem o direito de dar um sobrinho ou uma sobrinha. Portanto, pelo que se observa no texto, Nga Ndreza, como sobrinha, é entregue a um homem de bens, um patrão que ela passa a servir como criada, de quem, muitas vezes, recebe maus tratos. É na cidade, entenda-se, Luanda, onde decorrem todas as ações engendradas na narrativa, espaço de convívio entre brancos e negros, evidenciando racionalidades distintas, resultado do diálogo intercultural. 
O segundo momento dessa narrativa é referente à vida da mesma mulher, já com o nome de Nga Mutúri (senhora viúva), antropônimo que lhe é característico depois da morte do seu patrão, cujo testamento aponta-a como sendo a herdeira legítima dos bens.

Em 'Nga Mutúri', são notáveis as memórias individuais da senhora e não apenas as quais decorrem das suas experiências pessoais, evocadas em momentos próprios, como acontece quando demonstra a falta de conhecimento de seu pai. Porém, lembra-se de um homem que se preocupava com ela quando era menor, conforme conta o narrador "que não sabia bem - isto com ares maliciosos - quem era o pai, mas que se lembrava de um branco quando era pequenita, que a tomava nos braços e a sentava à mesa (Troni, 2014, p. 19).

Ao contrário disto, a narrativa em causa textualiza um conjunto de memórias impessoais, as quais refletem o pensamento grupal, no plano de superfície socio-histórico, justificando, dentre outros aspectos, a relação que o grupo estabelece com as suas práticas sociais com as quais se identifica. Pode-se constatar isso quando Nga Ndreza é abalada pela tristeza, por não ter filhos. Diante desta situação, as amigas, muito invejosas, diga-se a verdade, diziam que precisava ter um filho. "Lembraram-lhe promessas a Nossa Senhora da Muxima, ou que fizesse feitiços, e fê-los" (Troni, 2014, p.24-25). Aqui, está presente um aspecto mágico-religioso característico da mestiçagem cultural, própria de uma sociedade multicultural. Entende-se que "Nossa Senhora da Muxima",", marco espacial da memória cristã, representa o lugar do culto religioso aonde Nga Mutúri é sugerida a ir para pedir filhos.

O conhecimento de causa (compartilhado) que as amigas da viúva têm sobre esse lugar representa a funcionalidade da religião enquanto vetor da continuidade social. Por isso, de acordo com Rivera (2001), com quem concordamos, o culto cristão visa à reativação permanente da memória de seu fundamento; a crença religiosa é substancialmente uma forma de lembrar. A igreja fixou suas origens na forma de dogma, mas esse também se transforma. Portanto, toda mudança religiosa encontra sua legitimidade na afirmação de uma perfeita continuidade com suas origens. Essa continuidade dá-se por várias vias, tais como a prática incessante de rituais que asseguram e fundamentam as crenças herdadas do passado, assegurando o presente que se projeta para o futuro.

2. No contexto social, as origens remontam à construção da Igreja de Nossa Senhora da Conceição na localidade conhecida como Muxima, na atual província de Luanda, em 1599. O santuário logo se converteu num importante centro de cristianização, sendo o lugar onde se batizavam os africanos antes de embarcá-los como escravos para diversas localidades, mas em especial para as Américas. Tornou-se, igualmente, um importante espaço devocional para as populações cristãs autóctones, que logo atribuíram à Senhora da Muxima a realização de diversos milagres, como cura de doença e prosperidade na vida conjugal e social. (Anabengo, s.d.) 
O mesmo acontece com o cenário que diz respeito às exéquias do patrão de Nga Mutúri. Seguindo o narrador, percebe-se que depois da morte do senhor, o resto da narrativa fica muito marcado com aspectos sociais e religiosos. Estes revelam a visão de mundo da igreja católica, como se pode ler em “... e entrava o pároco com a face congestionada pela caminhada sobre o jantar comido à pressa e mal mastigado. Vinham dois sacristas, um com o hissope e o outro com a cruz. Entraram na sala guarnecida de negro nos alizares das portas, e o padre começou a rezar os responsos" (Troni, 2014, p. 28). Aqui, como no fragmento que se segue, observa-se o ritual das exéquias, entendido como um momento de esperança e de consolação. Consolação porque o defunto, incorporado pelo batismo em Jesus Cristo, passa da morte à vida, é purificado e seu corpo aguardará a ressurreição dos mortos. Por outro lado, isto é, na sequência do ritual acima referido, visualiza-se, na obra de Alfredo Troni, a missa após a morte.

O trecho que se segue é disso um exemplo. "Nga Mutúri estava na missa, muito grave, com os competentes panos de zuarte azul-escuro, o seu pano preto e um gorro, segundo o custume..." (Troni, 2014, p.30). Nesta e noutras práticas, pelo que entendemos, são lançadas expectativas de um post-mortem, realçando a transcendência do difunto para outro mundo, entenda-se, o paraíso. E, para o efeito, as missas, a cruz, as velas, o luto, etc. auxiliam na concretização dos desígnios dos fiéis que, à luz das suas crenças, meditam e oram a favor do morto. Na mesma narrativa, depois da morte do patrão da criada, entenda-se Nga Mutúri, enquanto se transporta o caixão ao cemitério, o narrador conta que

... logo o director do enterro começou a chamar o Cassabalo e o Burica que lavavam as trancas, e eles, do grande mar de machilas que afogava o enterro, surdiam segurando umas tungas [Do kimbundu tungu, paus, barrotes, madeira] forradas de negro com espirais de galão amarelo, que passaram por baixo do caixão, e com o Feliciano e o Baxi carregaram-no até à igreja do Carmo (Troni, 2014, p. 29).

Na mesma página, há uma nota de roda pé que explica que "têm as pretas por costume pôr aos filhos muitas vezes o nome do dia em que nasceu...”. Como é do conhecimento geral, é direito de toda a criança ter um nome. Entre os povos bantu, uma das formas de perpetuarem a sua memória coletiva tem a ver com a forma como os pais atribuem nomes aos seus filhos. Estão imersos em duas visões, a "tradicional", de que provêm elementos simbólicos que sustentam a identidade étnica, e a "moderna", que é associada ao exógeno. Considerando este fator, pode dizer-se que Cassabalo, enquanto antropônimo, não deixa de revelar a visão de mundo "tradicional" bantu e equivale ao que Ernest Gelnner, citado por Candau (2012), considera como sendo o "capital cognitivo fixo". Este "capital cognitivo fixo" é aqui entendido como herança histórico-cultural compartilhada. Visto o 
problema por esta perspectiva, concluímos que o nome, no fundo, na linha de Jean-Marie Benoist, também citado por Candau (2012), é o lugar da inscrição social do grupo sobre o sujeito. Nesta vertente, o nome é acima de tudo a linguagem das tradições, na medida em que pode ter várias dimensões, como a histórica (porque representa uma narrativa) e a espiritual (porque nele estão depositadas crenças que fundamentam o 'modus vivendi' a que o indivíduo pertence).

Depois das breves considerações em torno de 'Nga Mutúri', cabe-nos comentar 'Vozes na Sanzala (Kahitu)', narrativa de Uanhenga Xitu. Esta obra conta a história de um menino paralítico de nascença, Kahitu. A sua deficiência física deve-se ao fato de os seus pais não terem cumprido com determinados rituais "da terra" antes do seu nascimento. Ele é zombado muitas vezes por pessoas muito próximas a si, sobretudo por meninos como ele. Apesar da sua condição física, rastejando, frequenta a escola e é estimado pelos colegas e pelo professor por ser dedicado e inteligente, motivo por que, por exemplo, trabalha como escrivão e leitor de cartas, ofícios que the dão prestígio na comunidade onde vive. Tal como 'Nga Mutúri', 'Vozes na Sanzala (Kahitu)' não deixa de apresentar de maneira transperente as memórias individuais e coletivas evocadas tanto pelo narrador como pelas personagens.

Um dos casos que se pode elucidar tem a ver com as lembranças de Mukita, pai de Kahitu. Surpreendido com o nascimento do filho, exclama: "- que azar meu! Veja lá! Depois da mulher dar-me quatro filhos sãos, resolveu a Sereia mandar-me este kikata!..." (Xitu, 2013, p.62). Tão logo proferiu estas palavras, reconheceu que havia dito asneiras e retificou, dizendo que aceitara o que Deus lhe havia dado. "Muvumu, kitumba; mutunda njimu nhi kioua, mutunda o mukuá-sauidi nhi kinema" (Xitu, 213, p.62), que significa, conforme a nota de rodapé, "no ventre é como uma mata, sai o esperto e o néscio, o saldável e o eleijado". Esta fala é uma das provas evidentes da coabitação do Português e do Kimbundu na narrativa do escritor angolano, evocando, muitas vezes, saberes populares, provenientes das tradições orais africanas, no geral, e bantu, em particular. Esse aspecto prova a mobibilidade do pensamento humano no que diz respeito às múltiplas articulações feitas pelo homem para se comunicar em situações específicas.

No caso em estudo, observa-se a migração do provérbio dito na comunidade Ambundu para um suporte (o livro, no caso), evidenciando a intertextualidade que se opera mediante o processo de integração para legitimar o poder dos mortos sobre os vivos, se se considerar a censura que Mukita faz às próprias palavras. Este caso não é o único na obra em questão. Kahitu, por exemplo, quando chacoteado pelos meninos do seu bairro por se arrastar, ele agarra num e bate-o violentamente, o que leva a que Kialenguluka, mãe do prevaricador, indigne-se 
contra o paralítico. Em resposta, este diz "pedi-te muitas vezes para ralhar o teu filho, no meu lugar, mas nunca quer saber nada... Padeço mais com chacota dos vossos filhos - principalmente o teu filho - do que com os meus pés mortos. Jesus Cristo não esqueceu o aleijado..." (Xitu, 2013, p.93). Aqui, é notável a referência a uma memória religiosa, a qual se liga à narrativa bíblica acerca da cidade de Cafarnaum onde, milagrosamente, Jesus Cristo teria levantado um paralítico da cama, por ter fé em Deus. Na obra em análise, a alusão a Jesus Cristo, que "não esqueceu o aleijado...", é feita pelo Kahitu num momento de desolação e revela que o Messias lembra-se e cura os que padecem, como ele. Não é por acaso que, fazendo um recuo no tempo, recurso tecnicamente chamado analepse, rememora-se que, quando novo, frequentava a igreja e na cena de textos bíblicos que se referiam ao paralítico ele clamava: "Jesus, filho de David, tenha misercórdia de mim!" (Xitu, 2013, p.141).

$\mathrm{Na}$ mesma narrativa, mais adiante, narra-se o envolvimento amoroso entre Kahitu e Saki, uma jovem de corpo esbelto e muito desejada pelos homens da comunidade. A pedido de Kahitu, Saki nega revelar o caso às pessoas. Mais tarde fica concebida. Dando conta do assunto, a comunidade leva o caso ao tribunal, para que ele fosse julgado. Diante desta situação repugnante, Kahitu, que considera injusto o sistema judicial vigente, nega-se lá ir, apesar das deligências do oficial do Soba que tinha por missão levá-lo a Mbanza (Tribunal ou palácio do Soba). Kahitu, simulando ir ao quarto mudar o calção, toma um medicamento para matar gafanhotos e morre, fato que assombra a comunidade.

Ele seria sepultado no dia em que morreu, mas não aconteceu porque chovia intensamente, por isso só foi a enterrar no terceiro dia, num buraco cheio de água, sofrendo o povo por anos os efeitos da chuva. Antes disso, a Sanzala estava a ficar submersa e as trovoadas ensurdecedoras atemorizavam a comunidade. "Seria o Kahitu ou a vingança de Kahitu?” (Xitu, 2013, p.145), pergunta o narrador, que conta que "o vizinho do Baku, um velho corajoso quimbanda, conseguiu chegar às casas de alguns mágicos, convidando-os para nessa madrugada fazerem uma sessão de magia que fizesse atrair os raios que atormentavam a população da sanzala. Práticas antigas que deram efeitos no passado" (Xitu, 2013, p. 145).

Assim como vimos nos excertos anteriores, neste também há a evocação daquilo que chamamos universo de significações coletivas perpetuado na consciência de um grupo humano. A expressão 'práticas antigas que deram efeitos no passado'ilustra de forma nítida as crenças socio-culturais dos bantu, preexistentes aos indivíduos e aos grupos e estes são convocados para o presente, no contexto da narrativa, para solucionar um problema - que é evitar a submersão da sanzala, daí que realizam “exercícios de encantamentos, preces e cantos. Espalhou-se 
grãos de milho no chão, melhor dizer na água. De repente descem os raios em forma de galos de penas vermelhas" (Xitu, 2013, p.145)

Essas práticas ritualísticas são lembranças. Assim, como explica Candau (2012), com quem concordamos, encontram sua justificativa não apenas em assegurar uma continuidade fictícia ou real entre o passado e o presente, mas também em satisfazer uma lógica identificadora no interior do grupo, mobilizando deliberadamente a memória autorizada de uma tradição.

\section{Textualidade, estilo e variação linguística em Vozes na Sanzala (Kahi- tu) e Nga Mutúri}

Nesta seção, propomos apresentar os conceitos de textualidade, de estilo e de variação linguística, com vista a explicitar os aspectos que sujeitam o texto a uma dimensão linguística, por um lado, e a uma dimensão sociocultural, por outro. Estas dimensões vão, de certa maneira, mesclar-se ao conceito de memória discursiva, considerando quer a materialidade linguística dos textos, quer a sua dimensão social e, por isso, indiscutivelmente, o seu carácter identitário, seus autores e a comunidade primária de leitores a eles destinados.

\subsection{Textualidade}

O texto, como unidade suprafrásica, entende-se como uma cadeia de enunciados contendo uma unidade sociocomunicativa, uma unidade semântica e uma unidade formal. Neste caso, apesar de ser constituído por palavras, frases e enunciados, cumpre critérios rigorosos para que seja rotulado como tal. Assim, é indispensável que a sequência de palavras, frases ou enunciados que fazem os textos reúna um conjunto de propriedades que, no entender de Beaugrande e Dressler (1981), recebem o nome de 'textualidade'. Na opinião desses autores, a 'textualidade' compreende as seguintes propriedades ou critérios: coesão, coerência, intencionalidade, aceitabilidade, informatividade, intertextualidade e situacionalidade.

A definição muito mais explícita do conceito de 'textualidade' é a de Duarte (2003, p87), que a concebe como "o conjunto de propriedades que uma manifestação da linguagem humana deve possuir para ser reconhecida como texto". A autora considera como propriedades mais significativas a aceitabilidade, a situacionalidade, a intertextualidade, a informatividade e a conectividade, esta última integrando a coesão e a coerência propostas por Beaugrande e Dressler. Contrariamente a Duarte, Antunes (2010, p. 34), que também segue a proposta clássica de Beaugande e Dressler, por entender existirem propriedades que são mais diretamente relacionadas com a construção do texto e outras com as condições 
de sua efetivação, integra a coesão, a coerência, a informatividade e a intertextualidade nas primeiras e a intencionalidade, a aceitabilidade e a situacionalidade nas últimas.

A autora (op cit., p. 34) defende que a intencionalidade e a aceitabilidade, por exemplo, remetem aos interlocutores e não ao texto propriamente. Pela intencionalidade, o interlocutor propõe-se a dizer simplesmente aquilo que condiz, que é coerente. Por sua vez, o ouvinte/leitor empreende um esforço para processar os sentidos e as intenções expressas. Esta atividade do leitor/ouvinte relativamente às condições de efetivação do texto diz respeito à aceitabilidade. Da mesma forma, por situacionalidade, entende-se a condição indispensável para a materialização do texto como parte de uma atividade social, pois é bem claro que nenhum texto se produz fora de um contexto sociocultural determinado.

Para melhor percebermos a lógica da reorganização das propriedades da textualidade por Antunes (2010), atentemos ao que a literatura nos propõe como definição de cada um dos conceitos das propriedades atinentes ao texto propriamente:

i. A coesão, como referem Halliday e Hasan (1976), Antunes (2010), Koch (2014), entre outros, está ligada ao conceito semântico referente às relações de sentido existentes no interior do texto e permitem defini-lo como tal. Nesta perspectiva, com a coesão inter-relacionamos, ligamos ou encadeamos vários segmentos do texto, tais como palavras, orações, períodos e parágrafos;

ii. A coerência, na visão de Koch e Travaglia (2014, p.21), "está diretamente ligada à possibilidade de se estabelecer um sentido para o texto (...)", sendo ela que faz com que "o texto faça sentido para os usuários, devendo, portanto, ser entendida como um princípio de interpretabilidade, ligada à inteligibilidade do texto numa situação de comunicação e a capacidade que o receptor tem para calcular o sentido deste texto";

iii. A informatividade, de acordo com Antunes (2010) e Duarte (2003), consiste nos graus de novidade e de imprevisibilidade assumidos pelo texto em um dado contexto comunicativo, assim como no efeito interpretativo produzido pelo caráter inesperado de tais novidades;

iv. Por fim, a intertextualidade "designa a relação entre um determinado texto e outros textos relevantes, que fazem parte da experiência anterior do locutor/ escritor e do alocutário/ouvinte/leitor (Duarte, 2003, p. 88)".

Como se pode perceber, a proposta de Antunes (2010) chega a ser muito adequada para a percepção quer do carácter linguístico, quer do carácter sociocultural que integralizam o texto. Nesta perspectiva, podemos entender a textualidade como um conjunto de propriedades conducentes quer à interpretação de uma memória/tradição discursiva, quer à interpretação dos aspectos ligados à identidade linguística. 
No que diz respeito à memória/tradição discursiva, que inevitavelmente envolve a historicidade com que determinados textos são moldados, está fortemente ligada às propriedades entendidas por Antunes (2010) como condição para a efetivação do texto, por se vincularem às relações sociocomunicativas a que estão envolvidos quer o autor do texto, quer o ouvinte/leitor. Contudo, em parte, em se tratando da memória, integramos também nesta classe a intertextualidade, por entendermos que o entretecimento dos textos ocourre e se efetiva graças às experiências anteriores do locutor/escritor e do ouvinte/leitor, portanto à sua dimensão sociohistórica. Esta nossa posição é também encontrada em Duarte (2003, p. 88). Segundo a autora, a intertextualidade "relaciona um texto concreto com a memória textual coletica, com a memória de um grupo ou de um indivíduo específico". Vejamos como é que isto se dá nos dois textos, relevando, por exemplo, a situacionalidade.

No texto de Uanhenga Xitu, 'Kahitu', apresenta-se uma personagem principal, com o mesmo nome Kahitu, que nasceu com paralisia dos membros inferiores, como resultado da falta de oferendas ao Kilamba por parte do pai, como o afirma Kaualende, mãe de Kahitu, no seguinte excerto:

(1) "Mukita, ngemita dingi ${ }^{3}$. Espero que não vá suceder mais como na gravidez do Kahitu (...) sempre te fiz lembrar para dar o banquete ao Kituta de Kasadi, ou oferecer um presente ao nosso Kilamba assistente, como vinhas fazendo das anteriores vezes. (Xitu, 2013, p. 63)”.

A narrativa tem o seu pano de fundo nessa situação da paralisia de Kahitu, desde a discriminação, a falta de autoestima e a atribuição desse mal à violação dos princípios da tradição, como vimos no excerto. Esses aspectos, à volta da paralisia, situam o autor e o leitor em uma realidade sociocultural e simbólica explícitas, por corresponder a uma memória coletiva no seu todo, seguindo as tipologias de memória propostas por Candau (2012). Há ainda aqui a acrescentar as marcas da protomemória patentes no texto em abordagem, sobretudo no cenário do desmaio de Kaualende. Neste cenário, para além do comportamento dos animais e plantas que cumpriam o ritual para "o Mwene Kasadi não secar-lhes o manancial” (Xitu, 2014, p. 69), o narrador apresenta-nos um comportamento típico das comunidades bantu: proferir frases com agitamento de objetos e bailoçar de corpos, traduzindo profunda dor e consternação, aquando da manifestação da insatisfação pelo desmaio de Kaualende.

Na narrativa 'Nga Mutúri', de Alfredo Troni, a situacionalidade é resumida na relação patrão empregada/criada e nos efeitos socioculturais da herança. Essa 
narrativa, como vimos na primeira seção deste capítulo, conta a história da filha de uma mucama que se torna criada do patrão da falecida mãe e, depois, viúva desse patrão, merecendo a herança deste por deliberação do juiz que legitima esse direito, depois de apreciar as declarações e a idoneidade do testamenteiro, amigo próximo do falecido. Já para as propriedades da 'textualidade' ligadas ao texto propriamente, entendemos que estas, ainda incluindo a intertextualidade, têm um viés fortemente linguístico, envolvendo quer a unidade semântica, quer a unidade formal que permitem a integração do texto a uma determinada variedade linguística e a um gênero textual apropriado ao contexto, como se ilustra na subseção seguinte.

\subsubsection{Coesão textual}

A coesão textual, entendida por Duarte (2003) como conectividade sequencial, e a coerência textual, concebida pela mesma autora como conectividade conceptual, estão muito bem representadas nas narrativas de Alfredo Troni (Nga Mutúri) e de Uanhenga Xitu (Kahitu). Na presente subseção, tratamos de apresentar, sucintamente, alguns dados sobre a coesão textual presentes nas duas narrativas.

A autora citada (p. 90), considera como coesão textual (i) a coesão gramatical, que integra a coesão frásica, a coesão interfrásica, a coesão temporal, o paralelismo estrutural e a coesão referencial e (ii) a coesão lexical, que opera por contiguidade semântica, ou seja, pela co-presença de traços semânticos (total ou parcialmente) idênticos ou opostos. Neste caso, relevam-se a reiteração e a substituição (sinonímia, antonímia, heperonímia/hiponímia e holonímia/metonímia). Vejamos algumas marcas desse fator da textualidade nas narrativas em estudo.

\subsubsection{Coesão gramatical}

Coesão frásica: este tipo de coesão gramatical refere-se à ligação dos elementos linguísticos a nível sintagmático e oracional, tendo como foco os mecanismos de concordância e de ordem básica desses elementos na superfície textual. No seguinte excerto de Nga Mutúri, que reporta a fala de uma das personagens criadas por Troni, podemos notar a presença da concordância em número em 'contar as dobras' e em 'nove correntes de papagaio'.

(2) “《-Não.» - E pus-me a contar as dobras, eram nove. Depois levarantei a cabeça e disse-lhe: «-vale nove correntes de papagaio.»»" (Troni, 2014, p. 38).

Da mesma forma, recorrendo ainda à fala de algumas personagens das duas narrativas, nota-se a concordância em número e/ou em gênero na pronominalização a negrito. 
(3) “《- É latão, mulherzinha,»" - disse eu «enganaram-na.»” (Troni, 2014, p.38).

(4) "- Psiu, tudo para a rua! Fechem a porta, e tu, velha, cala-te - ordenou Kilamba." (Xitu, 2013, p. 75).

(5) "- Olhem, rapazes, o caso foi assim. Eu estava aqui onde estou, Nga Mutúri ali onde está o Silva, e o Taveira pouco mais ou menos onde está o Torres. Ela deu-me o grilhão para dizer quanto valia. Eu olhei, pesei-o, mas parecia-me história aquela bisarma de ouro." (Torni, 2014, p.37).

Nos casos apresentados nos excertos ( 2 - 5), notamos uma forte correspondência às regras de concordância. Contudo, para revelarem o que às vezes ocorre na fala, os narradores apresentam algumas variações típicas de Angola.

(6) "- Ngaku-kuata nga-ku-kuata ${ }^{4}$, Kipenze! (...). Sô sacana, vai pagar tudo o que me fizeste e aquilo que me fizeramos teus amigos (...). Anda a fazer pouco dos calos que trago no cu, não é?" (Xitu, 2013, p. 84).

(7) " $\underline{\mathrm{Tu}}$, Kialenguluka, também pode nascer, um dia, um filho como eu." (Xitu, 2013, p. 93).

(8) "- Mas tu quer ir mesmo com aquele rapaz de Mutamba? - perguntou Kahitu." (Xitu, 2013, p. 98).

Como se pode ver em (6), (7) e (8), a concordância em número não se cumpre nas formas verbais expressas, olhando para as pessoas gramaticais correspondentes. Em (6), 'vai pagar' remete para ele ou você e 'fizeste' remete para tu. Em se tratando da mesma pessoa, neste caso, Kipenze, esperava-se que a forma 'fizeste' passasse para 'fez' ou a forma 'vai pagar' passasse para 'vais pagar'. Do mesmo modo, a forma verbal ainda dependeria da concordância anterior. Em (7) e (8), igualmente, verifica-se que, mesmo com a referência ao 'tu', os verbos 'poder' e 'querer' são conjugados na terceira pessoa do singular, quando deveriam ser na segunda, respeitando a pessoa gramatical textualmente expressa.

Coesão temporal: este tipo de coesão gramatical refere-se à localização temporal dos acontecimentos na sequência textual, baseada na utilização correlativa de certos tempos verbais. Nas narrativas em estudo, a presença dessa coesão é ilustrada nos excertos seguintes.

(9) “(...) - que ela tivera culpa, porque enfim era menina nova, e o patrão não se importava com ela senão de meses a meses.” (Troni, 2014, p. 20).

(10) "- Eu não digo que não bate. Mas quando bate a mão não deve ficar muito pesado nos miúdos." (Xitu, 2013, p. 93).

Nos excertos apresentados, nota-se que os tempos verbais estão correlacionados e permitem a conectidade sequencial no prisma temporal, tendo em conta os 
critérios aspectuais da língua.

Paralelismo estrutural: de acordo com (Koch, 2014, p. 53), este tipo de coesão, também chamada sequencial ou sequenciação, "diz respeito aos procedimentos linguísticos por meio dos quais se estabelecem, entre segmentos do texto (enunciados, partes de enunciados, parágrafos e sequências textuais), diversos tipos de relações semânticas e/ou pragmáticas, à medida que se faz o texto progredir". Recorre-se frequentemente à sequenciação frástica e à sequenciação parafrástica. Contrariamente à segunda, a primeira sequenciação dispensa os procedimentos de recorrência. Esses procedimentos são atestados nas narrativas em estudo.

Vejamos como funciona a sequenciação frástica nas duas narrativas.

(11) "- Olhem, rapazes, o caso foi assim. Eu estava aqui onde estou, Nga Mutúri ali onde está o Silva, e o Taveira pouco mais ou menos onde $\underline{5}$ está o Torres. Ela deu-me o grilhão para dizer quanto valia. Eu olhei, pesei-o, mas parecia-me história aquela bisarma de ouro.” (Torni, 2014, p. 37).

(12) "- Eu estou a pensar que os teus pais vão te dizer, só estão a esperar o dia. Eles estão-te ainda a pôr medo para ver se você larga a namoração. Mas se eles advinharem o teu pensamento que aceitas ser raptada, vão dizer-te logo (...)." (Xitu, 2013, p. 101).

Nos dois casos apresentados, notamos que a progressão é desencadeada por uma série de unidades linguísticas que permitem a construção semântica do sentido. Como se pode perceber, não houve recorrência estrita a termos ou a estruturas anteriores, sendo o sentido construído por meio de correlação semântica entre as unidades.

Contrariamente à 'sequenciação frástica', nos excertos seguintes, dá-se o mecanismo da 'sequenciação parafrástica' baseada nos critérios de recorrência quer de termos, quer de estruturas, como se pode atestar nos seguintes excertos.

(13) "- Mentes, Mukita. Soube-se por aquele que fingiste consultar, quando a paralisia deu no kahitu. Pensas, porventura, o facto de eu estar calada há três anos, não sei causa da doença do meu filho? Tiveste vergonha de procurar o kilamba na doença do Kahitu, porque na minha gravidez não o fizeste (...). Pois digo-te, Mukita, enquanto Kahitu viver, será teu fardo. Porque com kituta não brinca.” (Xitu, 2013, p. 64).

(14) "- Que não sabia bem - isto com ares maliciosos - quem era o pai, mas que se lembrava de um branco quando era pequenita, que a tomava nos braços e a sentava à mesa (...).” (Troni, 2014, p. 19). 
Nos dois excertos, nota-se a recorrência aos termos paralisia e quem, respetivamente. Neste caso, o paralelismo faz-se com recurso a critérios lexicais que permitem a retoma dos termos principais usados na enunciação.

Coesão referencial: Koch (2014, p. 31) chama coesão referencial "aquela que um componente da superfície do texto faz remissão a outro (s) elemento (s) nela presentes ou inferíveis a partir do universo textual". Ou seja, este tipo de coesão diz respeito à:

propriedade de qualquer texto em que se assinale, através da utilização de formas linguísticas apropriadas, que os indivíduos designados por uma dada expressão são introduzidos pela primeira vez no texto, já foram mencionados no discurso anterior, situam-se no espaço físico perceptível pelo locutor/ escritor ou pelo alocutário/ouvinte/leitor, existem ou não como objetos únicos na memória destes." (Duarte, 2003, p. 111).

A coesão referencial pode ser do tipo 'exóforico (ou referência)', quando a relação referencial é controlada pragmaticamente, e 'endofórica (ou co-referência)', quando a referência é controlada por relações de dependência entre elementos expressos no texto. Enquanto a 'referência' depende da ativação de um espaço cognitivo garantido pelo discurso anterior e pela situação, a 'co-referência' depende da identificação de unidades/estruturas garantidas pela progressão do próprio texto, que, dentre outros aspectos, obedece a critérios de economia. Restringindo a nossa análise à referência endofórica, vejamos como este mecanismo se apresenta nas duas narrativas em estudo.

(15) "- Olhem, rapazes, o caso foi assim. Eu estava ${ }_{i}$ aqui onde estou, Nga Mutúri $[-]_{\mathrm{i}}$ ali onde está o Silva, e o Taveira $[-]_{\mathrm{i}}$ pouco mais ou menos onde está o Torre (...)." (Troni, 2014, p.37).

(16) “[Mesene Kilamba $]_{\mathrm{i}}$, nós sabemos que é o maior entre os maiores mestres. Porque representa as divindades das águas das chuvas, das lagoas, dos rios, dos mares, das ribeiras e das nascentes. Sem [vós $]_{i}$ não há água. E sem água não há vida. Não queremos entrar em litígio [consigo $]_{\mathrm{i}}$. Vamos sair, deixamo-lo trabalhar à vontade (...).” (Xitu, 2013, p. 74).

No primeiro excerto, notamos que a forma verbal 'estava' que devria ser repetida para marcar a localização de Nga Mutúri e Taveira é omitida, quer por questões de economia, quer pela sua evidente recuperabilidade. Para facilitar a recuperabilidade dessa forma verbal, usamos a base (i) na forma expressa e nas omissões correlacionadas. Neste caso, temos a coesão referencial que se designa por 'elipse'. Já no segundo excerto, a expressão 'Mesene Kilamba' é recuperada progressivamente pelas unidades 'vós' e 'consigo', conforme indicadas pela marca de recuperabilidade (i). Este tipo de retoma ou recuperabilidade chama-se 'anáfora'. 


\subsubsection{Coesão Lexical}

A coesão lexical é um mecanismo coesivo que se processa por contiguidade semântica, ou seja, a co-presença de traços semânticos idênticos ou opostos permitem a geração de sentidos quer a nível sintático, quer a nível semântico. Este tipo de coesão pode ser baseado na reiteração, que consiste na repetição de expressões linguísticas, e na substituição, que consiste em relações de oposição, de integração ou de equivalência entre tais expressões. Alguns casos práticos são reportados nas duas narrativas.

(17) "Próximo do corpo de Kaualende, levantavam-se três compridas palmeiras, sobre as quais andava um felpudo esquilo, muito irriquieto (...). O $\underline{n d e n g u}^{6}$ pulava de uma palmeira para outra (...)." (Xitu, 2013, p.68).

(18) “- Olhem, rapazes, o caso foi assim. Eu estava aqui onde estou, Nga Mutúri ali onde está o Silva, e o Taveira pouco mais ou menos onde está o Torres. Ela deu-me o grilhão para dizer valia. Eu olhei, pesei-o, mas parecia-me história aquela bisarma de ouro." (Torni, 2014, p. 37).

Nestes dois excertos, temos a 'sinonímia'. No primeiro caso, a sinonímia é feita entre uma palavra típica do português e uma emprestada do kimbundu. Já no segundo caso, o mesmo processo é garantido por duas palavras portuguesas que também se relacionam por 'sinonímia'.

\subsubsection{Coerência Textual}

A coerência textual é considerada por Duarte (2003, p.115) como um "fator de textualidade que resulta da interação entre os elementos cognitivos apresentados pelas ocorrências textuais e o nosso conhecimento do mundo".

(19) "Há muito que venho despertando a essa gente de que era tempo de se oferecer um banquete ao Kasadi. Mas... A água está a dimunuir, já não chega até lá ao fundo, na lavra do Kingolo; (...), agora surge este caso da tua filha!... Não teríamos evitado tudo isso se o povo ouvisse os meus conselhos?" (Xitu, 2013, p.71).

(20) "Pois sim, eu também disse aquilo só por falar. Que, deixa-me dizer-te, coitadinha dela se mo fizesse! Mas, meu amigo, eu não como miolo de enxergão, não tenho a tua boa fé, a mim ninguém me faz o ninho atrás de orelha." (Troni, 2014, p. 24).

\subsection{Estilo e Variação Linguística}

Depois de apresentarmos os mecanismos de textualidade nas duas narrativas em estudo, reservamos esta subseção para fazermos uma abordagem sobre o estilo e

6. Esquilo. No texto de Uanhenga Xitu, este termo aparece como um empréstimo do kimbundu ao português. 
variação linguística patentes nessas narrativas. Seguindo a visão laboviana apresentada por Hora (2014, p. 19-20), considera-se estilo "qualquer variável que se correlaciona a diferentes formas de dizer". As mesmas formas têm em conta, por um lado, um conjunto de restrições linguísticas, que podem promover ou inibir a aplicação de uma regra, e, por outro lado, restrições extralinguísticas, que integram uma categoria social, focalizando a fala de diferentes falantes, tendo em conta algumas variáveis sociolinguísticas como sexo, idade, etnia, entre outras, e uma categoria estilística, que focaliza as diferenças intrafalantes. Por sua vez, entendemos por variação linguística "as diferenças linguísticas que ocorrem numa sociedade, considerando o fato de a língua não ser um conjunto homogéneo" (Delbecque, 2006, p. 169).

Aqui, resolvemos analisar a variação estilística e linguística, com o objetivo de vermos os aspectos da dinamicidade da língua nas duas narrativas, considerando as variáveis sociolinguísticas que caracterizam os respectivos textos. Nas duas narrativas, os autores apresentam uma composição heterogênea das personagens participantes, o que demonstra claramente a diferença entre as escolhas linguísticas de uns e de outros. Em Nga Mutúri, por exemplo, apesar de a obra relevar mais a fala do narrador, quando se fazem intervir as personagens, a linguagem revela-se mais cuidada entre sujeitos brancos do que entre os pretos, como se pode observar, respectivamente, nos seguintes fragmentos.

(21) “(...) Pois sim, eu também disse aquilo só por falar. Que, deixa-me dizer-te, coitadinha dela se mo fizesse! Mas, meu amigo, eu não como miolo de enxergão, não tenho a tua boa fé, a mim ninguém me faz o ninho atrás de orelha." (Troni, 2014, p. 24).

(22) “- Porque, então, que querem? - dizia ele - quando me lembro não posso ter-me que me não ria." (Troni, 2014: 38).

Este critério de estratificação social é também notório em Kahitu. Depois de ter aprendido a ler e escrever, Kahitu tornou-se um grande escrivão, ocupando o seu tempo em ler e em escrever cartas para as senhoras que solicitavam tal serviço. Como se pode perceber, em relação a essas senhoras, Kahitu distingue-se socialmente com maior grau de instrução, o que implica diferenças nas suas escolhas linguísticas, apesar de todosapresentarem desvios em relação ao padrão europeu, como se pode atestar nos seguintes excertos.

(23) “- Pronto, acabei a carta. Mas você sabes porque o teu pai não gosta do Mbenza?

- Costumam dizer que é por causa dumas conversas que passou muito tempo com meu avô e avô do Mbenza. Eles já morreu. Eu tenho coisa com isso?" (Xitu, 2013, p. 101). 
(24) “- Não tem medo ou bocado de amor para Madima que gosta de tî?

- Não, ni o coração está pesado. Gosto é gosto. Já tenho meu rapaz (...)" (Xitu, 2013, p. 99).

Nos dois diálogos entre Kahitu e as suas interlocutoras, apesar de o mesmo apresentar problemas de concordância (pro)nominal, nota-se uma construção com pouca variação em relação a das outras. As interlocutoras apresentam vários problemas de linguagem, desde a concordância à seleção de unidades lexicais não características nem do kimbundu, nem do português.

Para além da variação estilística, que aqui restringimos às escolhas individuais das personagens estratificadas pelos respectivos narradores, há que se apresentar também os aspectos ligados à variação linguística quer por recurso a hibridismos entre o kimbundu e o português, quer por identificação de estruturas gramaticais muito características dos grupos sociais apresentados nos respectivos textos.

Relativamente aos hibridismos, nas duas narrativas, nota-se a tendência para os respectivos narradores fazerem recurso a palavras do kimbundu, ou por questões meramente estéticas, ou por falta de palavras portuguesas equivalentes. Vejamos alguns casos.

(25) “(...) cujo silêncio é só quebrado a espaços pelo seco bater, na areia da rua, dos pés dos gingamba ${ }^{7}$ que carregam uma machila ${ }^{8}$ ou pelos gritos estridentes das molecas da vizinhaça que apregoam ruidosas bonzo" (Troni, 2014, p. 16).

(26) "A mulher, pelo caminho, ia pensando no programa do dia. O carreiro por onde passava mal se via. O campim alto, pesado de $\underline{\text { dimune }}^{10}$, vergava sobre o caminho, impedindo a passagem. De vez em quando, com as mãos, a rapariga afastava o $\underline{\text { mbulu }}^{11}$ e o disenu ${ }^{12}$ que dificultavam o andamento (...)" (Xitu, 2013, p. 65).

Como se pode perceber nos dois excertos, algumas palavras em kimbundu, proferidas pelos respectivos narradores, são de uso estético, havendo correspondentes em português, como é o caso de 'gingamba' (carregadores) e de 'dimune' (orvalho). Outras, porém, só podem ter uma interpretação e não uma unidade lexical correspondente. Neste último caso, o narrador opta pela economia e pela

\footnotetext{
7. Carregadores, plural de mona ngamba.
}

8. Espécie de cadeirinha ou palaquim, usada na Índia e na África para transporte de pessoas.

9. Batata-doce, que está cozida, às portas das casas, e se oferece à venda, com azeite de palma, bananas, milho, etc. (cf. Alfredo Troni, Nga Mutúri, Luanda, União dos Escritores Angolanos, 2014,p.16)

10. Orvalho, água de chuva no capim.

11. Capim alto que se usa para cobertura de casas.

12. Capim para fabricar cestos. 
estética. Este recurso é também atestado por Perpétua Gonçalves na sua abordagem sobre 'influência de traços de línguas bantu' no português:

\begin{abstract}
No que diz respeito aos empréstimos, verifica-se que estes surgem em geral nos casos em que o léxico do $\mathrm{PE}^{13}$ não proporciona meios para a referência a realidades específicas de Moçambique ou de Angola, relativas à cultura (práticas religiosas, instrumentos musicais, pratos típicos), à fauna, à flora, a ainda a atividades económico-sociais típicas das sociedades moçambicanas e angolanas. (Gonçalves, 2013, p. $164-165)$.
\end{abstract}

A opção pela mesclagem de palavras do português e do kimbundu é algo característico de escritores africanos que, intentando fazer coabitar as línguas locais com a do colonizador, criam mecanismo para a vitalidade daquelas. Esta prática, embora se revele com pouco rigor à norma, abre espaços para a criatividade $\mathrm{e}$ para a variação diatópica de uma língua sociohistoricamente suscetível de profundas e inevitáveis mudanças. Cristine Severo considera este recurso como símbolo de identidade e de resistência:

Os géneros literários tendem a impor uma força normativa menor sobre as escolhas linguísticas, abrindo mais possibilidade para a criatividade linguística, como é o caso de uso de neologismos e de fenómenos de hibridismo entre diferentes línguas - certas literaturas pós-coloniais, por exemplo, mesclam as línguas locais e a língua do colonizador como bandeira de identidade e de resistência. (Severo, 2011 apud Severo, 2014, p. 40).

A mesclagem das línguas em causa acarreta consigo mudanças linguísticas profundas, considerando a possibilidade de a língua que acolhe a outra, neste caso o português, incorporar formas típicas da gramática da língua local, no caso o kimbundu. Em muitos contextos, como o atesta Gonçalves (2013, p. 165), por não se reconhecer os empréstimos como parte do léxico do português local, recorre-se à morfologia flexional das línguas bantu. Contudo, nos casos em que se reconhece o empréstimo como parte do léxico desse português, há a adoção da morfologia flexional do português. No seguinte excerto, por exemplo, a flexão de 'gingamba' e 'bonzo' obedece à morfologia das línguas bantu, na qual os nomes variam em número através da comutação de morfemas prefixais: em 'gi-ngamba' e 'gi-ponda', 'gi-“ é o prefixo que marca o plural, sendo 'ø-' o prefixo que marca o singular.

(27) “(...) cujo silêncio é só quebrado a espaços pelo seco bater, na areia da rua, dos pés dos gingamba que carregam uma machila ou pelos gritos estridentes das molecas da vizinhaça que apregoam ruidosas bonzo." (Troni, 2014, p. 16).

(28) “(...). Tirou também as giponda vestiu-se e apresentou-se na tesouraria da Junta ao empregado que ali estava (...).” (Troni, 2014, p. 41).

13. Português Europeu. 
Contudo, mesmo na narrativa de Troni, são registrados casos em que algumas palavras bantu assumem a morfologia flexional do português, como é o caso de 'macuta' »'macutas' (Troni, 2014, p. 20). Em casos como este, o empréstimo é reconhecido como parte do léxico do português. E isto dá-se mais visivelmente nos verbos, em que o morfema que marca a flexão morfológica do infinitivo impessoal ou a desinência modo-temporal e/ou número-pessoal evidencia o fato, como podemos atestar nos seguintes fragmentos.

(29) "Ele não sabia nadar, mas em terra, ou na água que lhe chegava até ao pescoço, ia dando as instruções aos seus pupilozinhos. Ensinando-os a fimbar ${ }^{14}$, nadar de costas, a nadar de lado e mais outras modalidades." (Xitu, 2013, p. 82).

(30) "A Mbombo cassunou ${ }^{15}$ o pano e mostrou e mostrou o sinal, que agora estava mais vivo, por causa do kikumbi ${ }^{16}$ que a rapariga trazia em toda a sua constituição física. E todos viram.” (Xitu, 2013, p. 78).

Outro aspecto de variação linguística a relevar, principalmente na narrativa Kahitu, deXitu (2013), é a presença de processos morfossintácticos alheios ao PE. Para além da questão da concordância em número e da omissão de determinantes verificados em (23) e (24), observam-se ainda casos de supressão e/ ou de adição de sons/sílabas, bem como de processos de ditongação e/ou de monotongação em algumas palavras: 'amadrugarem', 'madrugarem' (p.65); 'chatiar-me' 'chatear-me' (p. 90); 'juados', 'enjoados' (p. 93); 'feitiçar'/'feitiçou', 'enfeitiçar'/'enfeitiçou' (p. 98/101); 'migar' '17, 'amigar' (p. 100); 'gatinhar', 'engatinhar' (p. 102). Da mesma forma, podemos notar processos de formação de palavras típicas de Angola, como em 'namoração', 'namoro' (p. 101); 'lagrimar', 'lacrimejar' (p.75), entre outros.

Finalmente, urge também fazer referência à variação linguística a nível semântico, em que certas expressões equivalem a palavras já presentes na língua ou certas palavras perdem o seu sentido primário, tendo em conta o contexto enunciativo em que são empregues.

(31) "A filha de Jingondo lhe deram uma barriga na casa do pai dele." (Xitu, 2013, p. 100).

(32) "- Pois o Pinto enganou-a; este conhecimento é velho e é de outra décima. Ele comeu o dinheiro a Nga Mutúri.” (Troni, 2014, p. 42).

Como se pode notar pelos contextos dados, a expressão 'lhe deram barriga'

14. Mergulhar.

15. Desamarrou (v. kukasuna - desamarrar).

16. Viço; sinal de puberdade ou de gravidez.

17. O significado primário desta palavra é esmigalhar, esfarelar; no texto, é usada como equivalente a amigar (amistar, harmonizar). 
equivale a 'engravidaram-na' e a frase 'Ele comeu o dinheiro a Nga Mutúri' equivale a 'Ele gastou o dinheiro a (da?) Nga Mutúri'. Os sentidos derivados inscrevem-se numa variedade linguística específica, a do Português de Angola, podendo as expressões derivantes merecer outras interpretações por falantes de outras variedades do português. É perfeitamente inferível que 'dar barriga' venha a ser interpretado como um ato de oferecer barriga ou atribuir barriga a alguém, algo que pode ser encarado como muito subjetivo. De igual modo, 'comer dinheiro' pode ser interpretado como ingestão de dinheiro, um ato impróprio aos seres humanos. Portanto, os dois casos apresentados revelam uma identidade linguística inequívoca. Essa identidade é garantida pelo texto como lugar de memória coletiva, que envolve, para além da historicidade, recurso a formas linguísticas sucetíveis de manifestar as características socioculturais e, consequentemente, sociolinguísticas de um povo.

\section{Considerações Finais}

Neste estudo, foi nosso interesse demonstrar a maneira como os aspectos ligados às memórias coletivas e aos discursos se evidenciam linguisticamente nas narrativas de Uanhenga Xitu e Afredo Troni. As análises feitas permitem-nos concluir que, sendo os discursos a manifestação de subjetividade e ao mesmo tempo de socialidade, é indiscutível que estes não revelem a heterogeneidade dos saberes que absorvem, fazendo de cada discurso um evento inédito, carregado de elementos socio-culturais e históricos de caráter grupal. Estes aspectos estão espelhados nas narrativas estudadas, as quais mostram, ora de forma tênue ora de forma transparente, as articulações entre as experiências de grupos humanos com visões de mundo diferentes, mas que se cruzam, produzindo novos modos de pensar e agir dos sujeitos no contexto das narrativas em questão.

Quanto à construção da identidade linguística, na seção 2, foi demonstrado que quer a narrativa 'Nga Mutúri', de Alfredo Troni, quer a 'Kahitu', de Uanhenga Xitu, reportam a variedade angolana do português, considerando os vários aspectos estilísticos e variacionistas abordados. A primeira subseção, sobre a textualidade, serviu para demonstrar que, apesar da variação estilística e linguística, os textos dessas narrativas obedecem aos critérios de textualidade típicas do português, sobretudo no que diz respeito à coesão gramatical e à coerência. Contudo, as estruturas agramaticais, que pecariam relativamente à coesão frásica, sobretudo a concordância, ficam aqui consideradas como variação.

$\mathrm{Na}$ segunda subseção da seção 2 foram apontados alguns aspectos de variação estilística e linguística que permitiram caracterizar a variedade do português angolano, com recurso a estruturas gramaticais próprias. As restrições linguísticas e 
extralinguísticas observadas, em grande parte, caracterizam-se por um forte desvio à norma europeia, dando possibilidade a criatividades a nível morfossintático e semântico. Assim sendo, podemos concluir que as duas narrativas contribuem muito na construção da identidade linguística da variedade do Português de Angola, recorrendo aos dados da memória coletiva, que permitem reportar práticas linguísticas típicas das comunidades representadas nas respectivas narrativas.

\section{Referências}

Anabengo. A lenda da mamã muxima. S.d. Disponível em $<$ http://www.anabengo.org/Curiosidades_files/AnaBengo_A\%20lenda\%20da\%20Mam\%E2\%88\%86\%20Muxima.pdf $>$. Acesso em: 12 mar. 2017.

Antunes, Irandé. Lingua, Texto e Ensino: outra escola possível. São Paulo: Parábola Editorial, 2009.

Antunes, Irandé. Análise de textos: fundamentos e práticas. São Paulo: Parábola Editorial, 2010.

Bakhtin, Mikhail. Problemas da poética de Dostoiévski. Rio de Janeiro: Forense Universitária, 1981.

Beaugrande, Robert Alain de; Dressler, Wolfgang Ulrich. Introduction to text linguistics, London: Longman, 1981.

Candau, Joël. Memória e identidade, São Paulo: Contexto, 2012.

Delbeque, Nicole. Linguística cognitiva, Porto: Editora Piaget, 2006.

Duarte, Inês. Aspectos linguísticos da organização textual. In: Mateus, Maria Helena Mira et al. (Org.). Gramática da língua portuguesa. Lisboa: Caminho, 2003. p. 84-123.

Gonçalves, Perpétua. O Português em África. In: Paposo, Eduardo Buzaglo Paiva et al.. (Org.). Gramática do Português. Lisboa: Fundação Calouste Gulbenkian, 2013. p. 156-178.

Hall, Stuart. A identidade cultural na pós-modernidade. Rio de Janeiro: Lamparina, 2014.

Hallbwachs, Maurice. Memória coletiva, São Paulo: Centauro, 2012.

Halliday, Michael Alexander Kirkwood; Hasan, Ruqaiya. Cohesion in english, London: Longman, 1976.

Hora, Dermeval. Estilo: uma perspectiva variacionista. In: Görski, Edar Maria; Coelho, Izete Lehmkuhl; Souza, Christiane Maria Nunes de (Org.). Variação estilística: reflexões teórico-metodológicas e propostas de análise. Florianópolis: Insular. v.3, 2014. p. 19-30.

José, Nsimba. As narrativas orais ovimbundu como espaço de produção de sentidos. In: Leite, Ilka Boaventura; Severo, Cristine Gorski (Org.). Kadila culturas e ambientes: diálogos Brasil -Angola, São Paulo: Blucher, 2016. p. 183-198.

Kabatek, Johannes. Tradições discursivas e mudança linguística. In: LOBO, T. et al.(Org.). Rosae: linguística histórica, história das línguas e outras histórias. Salvador: EDUFBA, 2006.p.579588.

Koch, Ingedore G. Villaça. A coesão textual, 18ed., São Paulo: Contexto, 2014. 
Koch, Ingedore G. Villaça; Travaglia, Luiz Carlos. A coerência textual, 18.ed., São Paulo: Contexto, 2014.

Le Goff, Jacques. Memória: história e memória. Campinas: UNICAMP, 1990.

Longhin, Sanderléia Roberta. Tradiçoes discursivas: conceito, história e aquisição. São Paulo: Cortez, 2014.

Monteiro, Charles. Memória e esquecimento nas artes de lembrar a cidade de Porto Alegre nas crônicas de Nilo Ruschel. Nuevo Mundo Mundos Nuevos, Debates, 2006. Disponível em: <http:// nuevomundo.revues.org/index1534.html>. Acesso em: 12 mai. 2009.

Nora, Pierre. Entre memória e História: a problemática dos lugares. In: Projeto História: história e Cultura.v.10, dez. São Paulo, 1981.

Pratt, Mary Louise. Os olhos do império: relatos de viagem e transculturação. Bauru: EDUSC, 1999.

Richard, Nelly. Intervenções críticas. Belo Horizonte: Editora UFMG, 2002.

Ricoeur, Paul. A Memória, a história, o esquecimento. Campinas: Unicamp, 2007.

Rivera, Dario Paulo Barrera. Tradição, memória e modernidade: a precariedade da memória religiosa contemporânea. Estudo de Religião, Ano XIV, nº 18, junho de 2000, p.121-144.

Rivera, Paulo Barrera. Tradição e emoção religiosa: Sociologia do Protestantismo na América Latina. São Paulo: Olho d'água, 2001.

Sá, Ana Lúcia de. A confluência do tradicional e do moderno na obra de Uanhenga Xitu. Luanda: União dos Escritores Angolanos, 2004.

Samoyault, Tiphaine. A intertextualidade. São Paulo: Hucitec, 2008.

Severo, Cristine Gorski, Estilo. Variação Linguística e Discurso. In: Görski, Edar Maria; Coelho, Izete Lehmkuhl; Souza, Christiane Maria Nunes de (Org.). Variação Estilística: reflexões teórico-metodológicas e propostas de análise. Florianópolis: Insular, Coleção Linguística, v.3, 2014, p. 31-50.

Severo, Cristine Gorski. Línguas e Discursos: heterogeneidade linguístico-discursiva e poder em Angola. Veredas: Revista da Associação Internacional de Lusitanistas, v. 15, p. 19-46, 2011.

Silva, Tomaz Tadeu. Identidade e diferença: a perspectiva dos estudos culturais. Petrópolis: Vozes, 2003.

Troni, Alfredo. Nga Mutúri. Luanda: União dos Escritores Angolanos, 2014.

Xitu, Uanhenga. Mestre Tamoda e outros contos. Luanda: União dos Escritores Angolanos, 2003. 